\title{
Kepuasan Pernikahan Pasangan Beda Etnis ditentukan Resolusi Konflik dan Intimasi Spiritual
}

\section{Conflict Resolution and Spiritual Intimacy Predict Interracial Marital Satisfaction}

\author{
Alexandra Arvia, Jenny Lukito Setiawan \\ Fakultas Psikologi Universitas Ciputra, Surabaya, Indonesia
}

\begin{abstract}
The aim of this study was to examine the effect of conflict resolution and spiritual intimacy on marital satisfaction among interracial married couples. Subjects in this study were 51 interracial married couples in one of the church synods in Indonesia. Data were collected using conflict resolution, spiritual intimacy and marital satisfaction scales. Data analysis techniques used in this study were multiple and partial regression analysis. The result showed that there is an effect of conflict resolution and spiritual intimacy to marital satisfaction simultaneously. On the other hand, both conflict resolution and spiritual intimacy has their own roles towards marital satisfaction among interracial married couples. Nevertheless, compared with conflict resolution, spiritual intimacy has a bigger impact towards marriage satisfaction.
\end{abstract}

Keywords: Conflict resolution, marital satisfaction, spiritual intimacy

\begin{abstract}
Abstrak: Tujuan penelitian ini adalah menguji pengaruh resolusi konflik dan intimasi spiritual terhadap kepuasan pernikahan pada pasangan suami istri beda etnis. Subjek penelitian adalah 51 pasangan suami istri beda etnis pada salah satu sinode gereja di Indonesia. Penelitian ini menggunakan skala resolusi konflik, intimasi spiritual dan kepuasan pernikahan untuk mengumpulkan data. Teknik analisis data yang digunakan adalah uji regresi berganda. Analisis regresi linier berganda menunjukkan adanya pengaruh yang signifikan dari resolusi konflik dan intimasi spiritual terhadap kepuasan pernikahan secara simultan. Selain itu, baik resolusi konflik ataupun intimasi spiritual masing-masing memiliki peran terhadap kepuasan pernikahan pada pasangan Kristiani beda etnis. Meski demikian, dibandingkan dengan resolusi konflik, intimasi spiritual memberikan pengaruh yang lebih besar terhadap kepuasan pernikahan.
\end{abstract}

Kata kunci: Intimasi spiritual, kepuasan pernikahan, resolusi konflik

Pernikahan pasangan berbeda etnis berpeluang tinggi terjadi di Indonesia karena kemajemukan masyarakatnya dan migrasi seumur hidup dari masyarakat lintas daerah dan pulau di Indonesia (Pramudito, 2017). Meskipun belum ada data resmi terkait jumlah pernikahan beda budaya di Indonesia, namun indikasi tersebut dapat dilihat dari jumlah migrasi seumur hidup yang terjadi di Indonesia. Berdasarkan data sensus penduduk tahun 2010, sejumlah 27.975.612 orang atau $11,77 \%$ dari total penduduk Indonesia berpindah secara permanen dari tempat kelahirannya ke berbagai daerah lain di seluruh Indonesia (Pramudito, 2017).

Pernikahan beda etnis atau budaya lebih berpeluang memunculkan masalah

Korespondensi tentang artikel ini dapat dialamatkan kepada Alexandra Arvia melalui E-mail: arvialexandra@gmail.com 
dibanding pasangan dari budaya dan etnis yang sama. Masalah utama yang muncul adalah kesulitan dalam adaptasi karena munculnya bias dalam menilai pasangan akibat dari perbedaan dalam nilai-nilai yang dianut dan karakteristik kepribadian (Lee, Balkin, \& Fernandez, 2017; Skinner \& Hudac, 2017).

Persoalan yang dihadapi pasangan berbeda budaya tidak hanya terbatas pada pasangan itu sendiri, namun juga keluarga besar mereka. Apriani, Sakti, dan Fauziah (2013) melaporkan bahwa perempuan Jawa yang menikah dengan pria keturunan Tionghoa mendapatkan prasangka dari keluarga suami sebagai malas dan boros. Tuapattinaya dan Hartati (2014) juga melaporkan perempuan Jawa yang menikah dengan pria beda etnis mendapatkan penentangan dari keluarganya.

Masalah-masalah yang dihadapi pasangan berbeda etnis dan budaya tersebut berakibat pada tingginya potensi konflik yang terjadi yang pada akhirnya dapat berakhir dengan perceraian (Pramudito, 2017). Data dari Badan Pusat Statistik (BPS) nasional, seperti dipaparkan oleh Kumparan (2019), menunjukkan jumlah pernikahan dan perceraian naik pada tahun 2015 hingga 2017 dengan perkiraan terjadi 1 kali perceraian dari 5 kali pernikahan. Risiko perceraian tertinggi ada di Jawa Timur yaitu 1:3,75 dimana terjadi 1 perceraian dalam setiap 3 pernikahan. Dari 38.109 kasus perceraian tahun 2018 di Jawa Timur, 43,51\% diantaranya disebabkan oleh adanya pertengkaran terusmenerus, karena kondisi perekonomian (36,67\%), karena meninggalkan salah satu pasangan $(14,38 \%)$, dan karena kekerasan dalam rumah tangga $(1,66 \%)$ (Kumparan, 2019).

Data lain yang diperoleh dari Badan Kependudukan dan Keluarga Berencana Nasional (BKKBN, 2013) menunjukkan bahwa angka perceraian di Indonesia telah menduduki peringkat tertinggi di Asia Pasifik. Anwar Saadi, selaku Kasubdit
Kepenghuluan Direktorat Urais dan Binsyar Kementerian Agama menyatakan bahwa sejak tahun 2009 hingga 2016, angka perceraian di Indonesia mengalami kenaikan sebesar 16 hingga 20 persen (Choiriah, 2016; Purnawan, 2016). Adanya peningkatan angka perceraian di Indonesia dari tahun ke tahun tersebut dapat memberikan gambaran terkait kondisi kepuasan pernikahan pada masyarakat di Indonesia. Kepuasan pernikahan merupakan salah satu faktor penentu keberhasilan suatu pernikahan (Ardhianita \& Andayani, 2005).

Menurut Bahr, Chappell dan Leigh (1983), kepuasan pernikahan merupakan evaluasi secara keseluruhan dari kualitas hubungan antara pasangan suami istri yang bersifat subjektif. Hal ini berkaitan dengan tingkat pemenuhan kebutuhan, harapan dan hasrat dalam suatu pernikahan. Bagi pasangan beda etnis tentu hal ini memiliki tantangan tersendiri dalam mencapainya. Dengan adanya perbedaan-perbedaan tersebut, kemungkinan terjadinya konflik pada pasangan beda etnis cenderung lebih besar. Hal ini membuat pasangan beda etnis rentan terhadap perceraian.

Pada pasangan beda etnis, konflik lebih sering terjadi karena masing-masing pribadi memiliki sistem keyakinan, antara lain pola pikir, gaya bahasa, dan sikap, yang dilatarbelakangi budaya dan pengalaman yang berbeda (Dewi \& Basti, 2008). Hal ini didukung oleh Igbo, Grace, dan Christiana (2015) yang menyatakan bahwa semakin banyak perbedaan di antara pasangan maka semakin besar peluang terjadinya konflik.

Di sisi lain, konflik tidak selalu berkonotasi negatif. Adanya konflik mampu membuat hubungan pasangan menjadi lebih produktif, saling memahami dan lebih dekat satu sama lain (Igbo et al., 2015). Igbo et al. (2015) menyatakan bahwa seberapa sering konflik tersebut dapat diselesaikan menentukan seberapa sehat hubungan suami istri tersebut. Ini 
berarti pasangan beda etnis memerlukan resolusi konflik yang efektif untuk menyelesaikan konflik tersebut. Resolusi konflik yang dimaksud dalam penelitian ini adalah penyelesaian konflik yang bersifat interpersonal. Stinson, Bermudez, Gale, Lewis, Meyer dan Templeton (2017) menjelaskan bahwa permasalahan interpersonal ini mencakup permasalahan terkait peran dari jenis kelamin, perbedaan antar budaya dan relasi antara suami istri.

Menurut Olson dan Larson (2008), resolusi konflik merupakan kemampuan pasangan dalam mendiskusikan dan menyelesaikan perbedaan. Hal ini berkaitan dengan efektivitas pasangan dalam bertukar pendapat, ide, bahkan dalam kondisi sedang mengalami konflik (Olson \& Larson, 2008). Untuk mencapai resolusi konflik yang efektif, pasangan harus mampu bersikap terbuka dan jujur dalam mendiskusikan masalah, ide dan pendapat satu sama lain. Bahkan, ketika pasangan saling berselisih paham, mereka tetap harus mampu untuk saling berbagi perasaan (Olson, Olson-Sigg, \& Larson, 2008). Hal ini mendukung terciptanya persepsi dan pemahaman yang sama sehingga konflik dapat diselesaikan dan kepuasan pernikahan dapat terwujud.

Kendati demikian, pasangan beda etnis memerlukan tenaga dan waktu lebih banyak untuk beradaptasi dengan pasangannya. Hal ini dikarenakan banyaknya perbedaan di antara mereka. Contohnya seperti perbedaan persepsi antara etnis Tionghoa dan etnis Jawa dalam menanggapi budaya pernikahan. Bagi etnis Tionghoa, keluarga memiliki peran penting demi menentukan calon pasangan hidup anaknya. Sedangkan, bagi etnis Jawa, hak memilih dan menentukan pasangan hidup sudah diberikan sepenuhnya kepada anak (Hariyono, 2006).

Perbedaan penggunaan bahasa antara suami dan istri beda etnis juga menjadi konflik tersendiri dalam hal berkomunikasi (Adi, 2017). Adanya istilah lokal dari budaya masing-masing pihak serta intonasi dan volume suara yang digunakan seringkali menimbulkan terjadinya kesalahpahaman pada pasangan suami istri. Seperti halnya pada etnis Jawa, mereka cenderung menggunakan intonasi dan volume suara yang lemah lembut, halus, dan sopan berbeda dengan etnis Batak yang cenderung menggunakan intonasi dan volume suara yang keras dan tegas (Nugroho, Lestari, \& Wiendijarti, 2012). Dari berbagai pemaparan mengenai konflik yang dialami oleh pasangan beda etnis, peneliti menduga bahwa resolusi konflik merupakan variabel penting yang berhubungan dengan kepuasan pernikahan pada pasangan beda etnis.

Penelitian sebelumnya terkait resolusi konflik pada pernikahan belum banyak mengkaji pernikahan beda etnis. Misalnya, Agustin, Raharjo, dan Suprihatini (2013) mengkaji manajemen konflik pada pasangan berbeda agama. Penelitian yang secara khusus mengkaji resolusi konflik dan kepuasan pernikahan pada pasangan beda etnis juga belum ditemukan. Penelitian terkait topik ini masih dilakukan pada populasi umum. Misalnya, Utami dan Mariyati (2015) mengkaji dan menemukan adanya hubungan positif antara persepsi terhadap resolusi konflik suami dan kepuasan pernikahan pada istri yang bekerja. Penelitian Schneewind dan Gerhard (2014) juga menunjukkan kontribusi dari resolusi konflik dan kepribadian terhadap kepuasan pernikahan pada pasangan dengan usia pernikahan lima tahun pertama. Stinson et al. (2017) juga mengkaji resolusi konflik dan kehadiran dalam ibadah terhadap kepuasan pernikahan. Namun penelitian ini ini tidak dilakukan pada konteks pasangan beda etnis.

Menurut Gottman (dalam Stinson et al., 2017) terdapat tiga jenis resolusi konflik yakni avoidance, validating, dan volatile. Pasangan yang menggunakan jenis resolusi konflik avoidance cenderung untuk menghindari adanya ketidaksetujuan antar satu sama lain. Hal ini membuat pasangan tidak saling menyampaikan 
pendapat mereka secara pribadi kepada pasangannya dengan tujuan agar terhindar dari konflik pernikahan.

Pada pasangan yang menggunakan jenis resolusi konflik validating, pasangan cenderung untuk saling mendengarkan dan melakukan adanya proses timbal balik terkait harapan dan keinginan pasangan satu sama lain. Mereka berani untuk menghadapi konflik dan perbedaan yang ada serta mencari jalan tengah yang baik bagi kedua individu tersebut. Terakhir, pasangan dengan jenis resolusi konflik volatile, pasangan yang menunjukkan secara langsung dan terang-terangan adanya perbedaan diantara mereka dengan saling menginterupsi dan berdebat satu sama lain (Gottman dalam Stinson et al., 2017).

Dari ketiga jenis resolusi konflik yang telah dijelaskan, penelitian ini berfokus pada jenis resolusi konflik jenis validating. Hal ini juga didukung dari hasil penelitian Stinson et al. (2017) yang menyatakan bahwa jenis resolusi konflik validating ini dinilai lebih efektif untuk meningkatkan kepuasan pernikahan dibandingkan dengan jenis resolusi konflik lainnya. Minimnya temuan terkait resolusi konflik pada pasangan beda etnis membuat hal ini penting untuk diteliti kembali demi meningkatkan kepuasan pernikahan pasangan beda etnis.

Selain resolusi konflik, variabel yang diduga berperan penting dalam mencapai kepuasan pernikahan adalah intimasi spiritual. Spiritualitas merupakan kesadaran individu dalam mempelajari arti dari sebuah cobaan, rasa syukur, iman sesuai dengan keyakinan terhadap sesuatu hal yang lebih besar dari dirinya (Ardian, 2016). Hal ini bertujuan sebagai upaya untuk mencari pemaknaan hidup dan kedamaian dalam diri individu. Pernyataan tersebut didukung dari hasil penelitian terdahulu (Rostami \& Gol, 2014; Fincham, Ajayi, \& Beach, 2011) yang menyatakan bahwa spiritualitas memiliki keterkaitan dengan kepuasan pernikahan.
Zahra dan Caninsti (2016) mengungkapkan bahwa spiritualitas adalah landasan bagi individu dalam menjalani kehidupan pernikahannya. Pada pernikahan beda etnis, konflik yang terjadi tidak hanya melibatkan salah satu pihak saja. Adanya landasan yang sama membantu pasangan meminimalisir perbedaan yang ada di antara mereka. Menurut Lichter dan Carmalt (2008), akan jauh lebih penting bagi pasangan untuk dapat saling berbagi keyakinan yang sama daripada memiliki afiliasi religiusitas yang sama.

Regnerus dan Elder (dalam Stinson et al., 2017) mendefinisikan religiusitas sebagai frekuensi kehadiran dan keaktifan individu di tempat ibadah. Hal ini berbeda dengan spiritualitas yang dimiliki individu meskipun keduanya sering kali dianggap mirip karena terlibat dalam menghadapi pergumulan hidup masing-masing pribadi (Stinson et al., 2017). Perbedaaan utama dari spiritualitas dengan religiusitas ialah sifat spiritualitas yang personal dan subjektif dibandingkan dengan religuisitas yang dinilai berdasarkan partisipasi pada sebuah kelompok keagamaan (Fincham, Ajayi, \& Beach, 2011). Penelitian ini berfokus pada spiritualitas individu bukan religiusitas.

Intimasi spiritual, menurut Kusner, Mahoney, Pargament dan Demaris (2014), merupakan hubungan atau relasi yang melibatkan pasangan untuk saling berbagi dan mendukung satu sama lain dalam hal spiritual. Kusner et al. (2014) menyatakan bahwa intimasi spiritual terdiri atas empat aspek, yaitu adanya keterbukaan spiritual (spiritual disclosure-self dan spiritual disclosure-spouse) dan dukungan antar pasangan suami istri (support-spouse dan support-self).

Intimasi spiritual yang tinggi ditandai dengan kemampuan pasangan untuk saling terbuka dan jujur kepada pasangannya tentang pergumulan-pergumulan spiritual mereka (Kusner et al., 2014). Ketika pasangan dapat membicarakan tentang halhal atau kesalahan terburuk yang melanggar prinsip dan nilai spiritual mereka 
(sering disebut sebagai aib atau dosa) terhadap pasangannya. Keterbukaan ini menjadi salah satu kunci dalam menumbuhkan kepercayaan satu sama lain (Brelsford \& Mahoney, 2008). Alasannya karena mengungkap pergumulan ataupun masalah pribadi bukanlah hal yang mudah untuk dilakukan jika tidak disertai dengan rasa saling percaya. Rasa saling percaya inilah yang akan menumbuhkan sebuah keintiman bagi pasangan suami istri. Pasangan akan saling menjaga agar tidak jatuh di lubang yang sama dengan cara saling mendukung, menasehati dan mengingatkan satu sama lain. Hal ini tentu tidak terlepas dari persamaan prinsip dan nilai yang dianut oleh mereka.

Berdasarkan data dari Badan Pusat Statistik (BPS, 2019), umat Kristiani merupakan umat dengan agama terbesar kedua di Indonesia. Ini berarti pernikahan dalam konteks Kristiani juga tidak sedikit ditemui di Indonesia. Hal yang menarik dalam pernikahan Kristiani ialah relasi antara suami istri dan Tuhan diibaratkan ke dalam bentuk ruang segitiga (Apostolic Christian Counseling and Family Services, 2014). Hal ini menjelaskan bahwa dalam pernikahan Kristiani terdapat tiga hubungan, yakni suami dengan Tuhan, istri dengan Tuhan dan suami dengan istri. Untuk mencapai adanya intimasi spiritual, baik suami maupun istri keduanya perlu adanya hubungan personal dengan Tuhan. Semakin dekat hubungan masing-masing pihak dengan Tuhan maka semakin dekat juga hubungan di antara suami istri tersebut.

Hal ini sesuai dengan beberapa pernyataan dari penelitian sebelumnya (Giblin dalam Fincham et al., 2011; David \& Stafford, 2013) bahwa faktor utama dalam meningkatkan kepuasan pernikahan ialah relasi spiritual yang dimiliki tiap pasangan suami istri bersama dengan Tuhan. Masing-masing relasi baik yang terjadi dalam diri suami maupun istri dengan Tuhan memengaruhi komunikasi yang baik diantara keduanya. Komunikasi ter- sebut secara langsung mampu meminimalisir konflik yang terjadi sehingga kualitas pernikahan dapat meningkat.

Dalam iman Kristiani diyakini bahwa manusia terdiri dari tiga unsur yaitu tubuh, jiwa, dan roh (Bunyamin, 2012). Karena itu, dalam pernikahan Kristiani, baik suami maupun istri harus saling terkoneksi melalui tiga unsur tersebut. Suami istri melakukan hubungan seksual untuk terkoneksi secara fisik. Resolusi konflik dan komunikasi diperlukan agar keduanya terkoneksi secara psikologis (unsur jiwa), sedangkan intimasi spiritual berperan menghubungkan unsur roh pada pasangan suami istri (Bunyamin, 2012).

Hasil penelitian sebelumnya yang hampir serupa dengan penelitian ini adalah penelitian Stinson et al. (2017) pada pasangan Latin terkait jenis resolusi konflik serta kehadiran religiusitas pasangan dalam memprediksi adanya perubahan pada kepuasan pernikahan. Stinson et al. (2017) mengungkapkan pasangan yang mampu menyelesaikan konflik dengan saling menerima dan mendiskusikan adanya perbedaan pendapat memiliki resolusi konflik yang lebih efektif. Stinson et. al (2017) juga menambahkan bahwa pasangan yang tekun dan aktif untuk hadir di kegiatan religiusitas memiliki resolusi konflik yang lebih baik serta kepuasan pernikahan yang lebih tinggi dibandingkan pasangan yang tidak aktif dalam kegiatan religiusitas.

Beberapa penelitian mengenai spiritualitas terhadap kepuasan pernikahan memang masih lebih sedikit ditemukan jika dibandingkan dengan religiusitas (Fincham et al., 2011; Rostami \& Gol, 2014; Mahoney \& Cano, 2014). Meski demikian, spiritualitas diyakini amat memengaruhi proses dalam sebuah relasi pernikahan (Lichter \& Carmalt, 2008).

Penelitian-penelitian terdahulu terkait hubungan antara spiritualitas dengan kepuasan pernikahan masih terdapat inkonsistensi. Pada beberapa penelitian sebelumnya ditemukan bahwa spiritualitas memi- 
liki hubungan dengan kepuasan pernikahan (Fincham et al., 2011; Kusner et al., 2014; Mahoney \& Cano, 2014; Rostami \& Gol, 2014). Sayangnya penelitian tersebut dilakukan di budaya Barat. Sebaliknya, penelitian Zahra dan Caninsti (2016) mengenai spiritualitas di budaya Timur menemukan bahwa tidak ada hubungan antara kepuasan pernikahan dengan spiritualitas pada istri yang bekerja dalam konteks Islami. Penelitian lain dari Zarei dan Ahmadisarkhooni (2013) juga menyatakan bahwa tidak ada keterkaitan antara spiritual quotient dengan kepuasan pernikahan. Dengan demikian, intimasi spiritual masih menjadi faktor yang dipertanyakan dalam memprediksi adanya perubahan pada kepuasan pernikahan pasangan Kristiani beda etnis.

Penelitian ini menguji tiga hipotesis. Hipotesis pertama adalah resolusi konflik dan intimasi spiritual berperan signifikan terhadap kepuasan pernikahan pada pasangan beda etnis. Hipotesis kedua, resolusi konflik berperan signifikan terhadap kepuasan pernikahan pada pasangan beda etnis. Hipotesis ketiga, intimasi spiritual berperan signifikan terhadap kepuasan pernikahan pada pasangan beda etnis.

\section{Metode}

Penelitian kuantitatif ini merupakan studi korelasional menggunakan tiga variabel yakni resolusi konflik dan intimasi spiritual sebagai variabel bebas dan kepuasan pernikahan sebagai variabel terikat.

\section{Sampel}

Penelitian ini menggunakan teknik total population study. Hal ini dikarenakan jumlah populasi yang tidak banyak yakni kurang lebih 100 orang. Subjek pada penelitian ini berjumlah 51 pasangan suami istri beda etnis yang berada di salah satu sinode gereja di Indonesia. Kriteria subjek penelitian yang digunakan oleh peneliti yaitu: a) pasangan suami istri yang berbeda etnis, b) merupakan anggota komunitas pernikahan di gereja tempat penelitian, c) tinggal bersama sebagai pasangan. Suku atau budaya dari pasangan beda etnis dari sampel penelitian ini keseluruhan dapat dilihat pada tabel 1 .

Tabel 1. Distribusi Pasangan Beda Etnis

\begin{tabular}{|c|c|c|c|}
\hline Pasangan & Beda etnis & Jumlah & Persentase \\
\hline \multirow{8}{*}{ Jawa } & Batak & 7 pasangan & $13,7 \%$ \\
\hline & Tionghoa & 10 pasangan & $19,6 \%$ \\
\hline & Bali & 2 pasangan & $3,9 \%$ \\
\hline & Rote, NTT & 4 pasangan & $7,8 \%$ \\
\hline & Toraja & 1 pasangan & $1,96 \%$ \\
\hline & Ambon & 3 pasangan & $5,9 \%$ \\
\hline & Manado & 2 pasangan & $3,9 \%$ \\
\hline & Bugis & 1 pasangan & $1,96 \%$ \\
\hline \multirow{6}{*}{ Batak } & Tionghoa & 6 pasangan & $11,8 \%$ \\
\hline & Bali & 1 pasangan & $1,96 \%$ \\
\hline & Rote, NTT & 2 pasangan & $3,9 \%$ \\
\hline & Toraja & 2 pasangan & $3,9 \%$ \\
\hline & Ambon & 2 pasangan & $3,9 \%$ \\
\hline & Madura & 1 pasangan & $1,96 \%$ \\
\hline \multirow[b]{2}{*}{ Tionghoa } & Sunda & 1 pasangan & $1,96 \%$ \\
\hline & Eropa & 1 pasangan & $1,96 \%$ \\
\hline \multirow[b]{2}{*}{ Bali } & Rote, NTT & 1 pasangan & $1,96 \%$ \\
\hline & Ambon & 1 pasangan & $1,96 \%$ \\
\hline Dayak & RoteNTT & 1 pasangan & $1,96 \%$ \\
\hline Manado & Toraja & 1 pasangan & $1,96 \%$ \\
\hline Ambon & Kalimantan & 1 pasangan & $1,96 \%$ \\
\hline Total & - & 51 pasangan & $100 \%$ \\
\hline
\end{tabular}

Dalam penelitian ini, pasangan beda etnis yang dimaksud adalah pasangan suami istri yang berasal dari suku budaya asli yang berbeda. Penentuan kriteria beda etnis ini penting dirumuskan mengingat adanya fenomena bicultural identity. Bicultural identity merupakan fenomena dimana individu memiliki lebih dari satu budaya sebagai budaya dasar atau original cultural (Yamaguchi, Kim, Oshio, \& Akutsu, 2016). Hal ini dikarenakan adanya kemajuan teknologi dan mobilitas antar 
Tabel 2. Demografis Subjek Penelitian

\begin{tabular}{|c|c|c|c|}
\hline \multicolumn{2}{|c|}{ Distribusi Demografi } & \multirow{2}{*}{$\frac{\text { Jumlah }}{51}$} & \multirow{2}{*}{$\frac{\text { Persentase }}{50 \%}$} \\
\hline Jenis & Laki-laki & & \\
\hline Kelamin & Perempuan & 51 & $50 \%$ \\
\hline \multirow{7}{*}{ Usia } & $27-32$ & 8 & $7,8 \%$ \\
\hline & $33-38$ & 53 & $52,2 \%$ \\
\hline & $39-44$ & 29 & $28,4 \%$ \\
\hline & $45-50$ & 7 & $6,9 \%$ \\
\hline & $51-56$ & 3 & $2,9 \%$ \\
\hline & $57-62$ & 1 & $0,9 \%$ \\
\hline & $63-68$ & 1 & $0,9 \%$ \\
\hline \multirow{5}{*}{$\begin{array}{l}\text { Usia } \\
\text { Perkawinan }\end{array}$} & $<5$ tahun & 24 & $23,5 \%$ \\
\hline & $6-11$ tahun & 30 & $29,4 \%$ \\
\hline & $12-17$ tahun & 38 & $37,2 \%$ \\
\hline & $18-23$ tahun & 8 & $7,8 \%$ \\
\hline & $>24$ tahun & 2 & $2 \%$ \\
\hline \multirow{4}{*}{$\begin{array}{l}\text { Lama } \\
\text { Berpacaran }\end{array}$} & $<1$ tahun & 29 & $28,4 \%$ \\
\hline & $1-3$ tahun & 66 & $64,7 \%$ \\
\hline & $4-6$ tahun & 5 & $4,9 \%$ \\
\hline & $6-9$ tahun & 2 & $2 \%$ \\
\hline \multirow{4}{*}{$\begin{array}{l}\text { Jumlah } \\
\text { Anak }\end{array}$} & 0 & 18 & $17,6 \%$ \\
\hline & 1 & 32 & $31,4 \%$ \\
\hline & 2 & 36 & $35,3 \%$ \\
\hline & 3 & 16 & $15,7 \%$ \\
\hline \multirow{7}{*}{ Pendidikan } & SD & 1 & $1 \%$ \\
\hline & SMP & 5 & $4,9 \%$ \\
\hline & SMA & 59 & $57,8 \%$ \\
\hline & Diploma & 14 & $13,7 \%$ \\
\hline & $\mathrm{S} 1$ & 21 & $20,6 \%$ \\
\hline & $\mathrm{S} 2$ & 1 & $1 \%$ \\
\hline & S3 & 1 & $1 \%$ \\
\hline \multirow{3}{*}{$\begin{array}{l}\text { Status } \\
\text { Pekerjaan }\end{array}$} & Tidak bekerja & 19 & $18,6 \%$ \\
\hline & Part-time & 22 & $21,6 \%$ \\
\hline & Full time & 61 & $59,8 \%$ \\
\hline \multirow{6}{*}{$\begin{array}{l}\text { Penghasilan } \\
\text { (per bulan) }\end{array}$} & $\begin{array}{c}\text { Tidak } \\
\text { berpenghasilan }\end{array}$ & 16 & $15,7 \%$ \\
\hline & $<5$ juta & 53 & $52 \%$ \\
\hline & $5-10$ juta & 24 & $23,5 \%$ \\
\hline & 10-15 juta & 6 & $5,9 \%$ \\
\hline & $15-20$ juta & 2 & $2 \%$ \\
\hline & $>20$ juta & 1 & $1 \%$ \\
\hline \multirow{14}{*}{$\begin{array}{l}\text { Suku/Asal } \\
\text { daerah }\end{array}$} & Jawa & 30 & $29,4 \%$ \\
\hline & Batak & 22 & $21,6 \%$ \\
\hline & Tionghoa & 18 & $17,6 \%$ \\
\hline & $\begin{array}{l}\text { Rote, Timor, } \\
\text { Kupang, NTT }\end{array}$ & 8 & $7,8 \%$ \\
\hline & $\begin{array}{c}\text { Ambon, Maluku, } \\
\text { Halmahera }\end{array}$ & 7 & $6,9 \%$ \\
\hline & Bali & 4 & $3,9 \%$ \\
\hline & Toraja & 4 & $3,9 \%$ \\
\hline & Manado & 3 & $2,9 \%$ \\
\hline & Sunda & 1 & $1,0 \%$ \\
\hline & Madura & 1 & $1,0 \%$ \\
\hline & Dayak & 1 & $1,0 \%$ \\
\hline & Kalimantan & 1 & $1,0 \%$ \\
\hline & Bugis & 1 & $1,0 \%$ \\
\hline & Eropa & 1 & $1,0 \%$ \\
\hline
\end{tabular}

wilayah yang memudahkan terjadinya pembauran dua kultur budaya dasar. Seperti pada individu keturunan Tionghoa yang lahir di Jawa namun menetap di Bali. Jika mayoritas kultur budaya yang dianut adalah Tionghoa maka identitas kultural individu tersebut adalah Tionghoa.

Berdasarkan distribusi demografis (pada tabel 2), diketahui bahwa proporsi suami dan istri dalam subjek penelitian termasuk seimbang yakni masing-masing sebesar 50\%. Berdasarkan usia, 80,6\% subjek penelitian berada pada rentang usia 33 hingga 44 tahun. Dilihat dari usia perkawinan subjek, sekitar $66,8 \%$ berada pada rentang 6 hingga 17 tahun. Mayoritas subjek berpacaran sebelum menikah selama satu hingga tiga tahun $(64,7 \%)$. Sebagian besar subjek penelitian memiliki satu hingga dua orang anak, yakni 66,7\%.

Dari segi pendidikan terakhir, subjek penelitian didominasi oleh lulusan SMA, diploma, dan S1 sederajat dengan persentase sebesar $92,1 \%$. Lebih dari setengahnya yakni $59,8 \%$, subjek penelitian memiliki pekerjaan full-time. Dilihat dari segi penghasilan, 91,2\% subjek berpenghasilan per bulan di bawah Rp 10.000.000. Dari segi suku atau budaya, subjek penelitian didominasi oleh tiga suku atau etnis, yakni suku Jawa (29,4\%), Batak (21,6\%), dan Tionghoa $(17,6 \%)$.

\section{Pengumpulan Data}

Penelitian ini menggunakan tiga skala yang dilengkapi dengan pengisian data demografis. Skala tersebut berupa skala Resolusi Konflik dari PREPARE/ ENRICH: Customized Version (Olson \& Larson, 2008) yang terdiri dari 10 aitem, skala Intimasi Spiritual yang dikembangkan oleh Kusner et al. (2014) terdiri dari 8 aitem, dan skala Kepuasan Pernikahan yang diadaptasi dari Kansas Marital Satisfaction Scale (Grable \& Britt, 2006) yang terdiri dari 3 aitem. Cara pengisian skala ini berbentuk skala Likert dengan lima kategori yang diberi skor 1 (sangat 
tidak setuju/tidak puas) hingga skor 5 (sangat setuju/puas). Ketiga skala ini telah diterjemahkan ke dalam Bahasa Indonesia oleh Kurniawan dan Setiawan (2016).

Pada penelitian ini, skor nilai uji reliabilitas pada skala resolusi konflik sebesar $\alpha=0,697$. Sedangkan, pada skala Kansas Marital Satisfaction yakni sebesar $\alpha=0,940$ dan skala intimasi spiritual sebesar $\alpha=0,827$. Dapat disimpulkan dari hasil tersebut bahwa skala resolusi konflik, skala kepuasan pernikahan, dan skala intimasi spiritual memiliki reliabilitas yang cukup tinggi.

\section{Analisis Data}

Uji hipotesis dilakukan dengan uji analisis regresi berganda untuk mengetahui kontribusi dari resolusi konflik dan intimasi spiritual terhadap kepuasan pernikahan pada pasangan beda etnis. Selain itu, peneliti juga ingin mengetahui seberapa besar kontribusi yang diberikan dari kedua variabel tersebut terhadap kepuasan pernikahan pasangan beda etnis.

\section{Hasil}

Hasil mean dan standar deviasi variabel resolusi konflik, intimasi spiritual, dan kepuasan pernikahan pada penelitian ini tercantum pada tabel 3 .

Tabel 3. Mean dan Standar Deviasi

\begin{tabular}{lcc}
\hline \multicolumn{1}{c}{ Variabel } & Mean & SD \\
\hline Resolusi Konflik & 3,310 & 0,599 \\
Intimasi Spiritual & 4,250 & 0,580 \\
Kepuasan & 4,390 & 0,704 \\
Pernikahan & & \\
\hline
\end{tabular}

Hasil tersebut menunjukkan bahwa subjek penelitian sudah cukup mampu untuk memiliki resolusi konflik yang efektif dan intimasi spiritual yang tinggi sehingga kepuasan pernikahan dapat tercapai.

Hasil uji hipotesis juga menunjukkan bahwa ketiga hipotesis dapat diterima (tabel 4). Hasil uji statistik menunjukkan adanya peran yang signifikan dari resolusi konflik dan intimasi spiritual terhadap kepuasan pernikahan pada pasangan beda etnis $\left(R=0,566 ; R^{2}=0,320 ; F=23,335\right.$; $\mathrm{p}<0,050)$. Berdasarkan hasil tersebut didapati bahwa baik resolusi konflik ataupun intimasi spiritual masing-masing memiliki peran terhadap kepuasan pernikahan pada pasangan kristiani beda etnis. Meski demikian, dibandingkan dengan resolusi konflik $(B=0,251)$, intimasi spiritual memiliki peran yang lebih besar terhadap kepuasan pernikahan $(B=0,516)$.

Tabel 4. Hasil Uji Hipotesis

\begin{tabular}{|c|c|c|c|c|c|c|}
\hline \multirow{2}{*}{ Model } & \multirow[t]{2}{*}{$\mathrm{R}^{2}$} & \multicolumn{2}{|c|}{$\begin{array}{l}\text { Unstandard- } \\
\text { Ized Coef. }\end{array}$} & \multirow{2}{*}{$\begin{array}{c}\begin{array}{c}\text { Standar } \\
\text { dized } \\
\text { Coef. }\end{array} \\
\text { Beta }\end{array}$} & \multirow{2}{*}{. } & \multirow[t]{2}{*}{ Sig. } \\
\hline & & B & $\begin{array}{l}\text { Std. } \\
\text { Error }\end{array}$ & & & \\
\hline $\mathrm{KP}$ & 0,320 & - & 0,586 & - & - & 0,000 \\
\hline RK & 0,033 & 0,251 & 0,114 & 0,214 & 2,205 & 0,020 \\
\hline IS & 0,287 & 0,516 & 0,118 & 0,425 & 4,391 & 0,000 \\
\hline \multirow[t]{2}{*}{ Model } & $\mathrm{R}$ & $\begin{array}{l}\text { Adj. } \\
\mathrm{R}^{2}\end{array}$ & $\begin{array}{l}\text { Std. } \\
\text { Err. of } \\
\text { the Est. }\end{array}$ & \multicolumn{3}{|c|}{ Chg. Statistics } \\
\hline & & & & $\begin{array}{c}\text { F } \\
\text { Chg. }\end{array}$ & $\begin{array}{cc}\text { Df } & \text { Df } \\
1 & 2\end{array}$ & $\begin{array}{l}\text { Sig. F } \\
\text { Chg. }\end{array}$ \\
\hline $\mathrm{KP}$ & 0,566 & 0,599 & 0,568 & 23,335 & 299 & 0,000 \\
\hline
\end{tabular}

Predictor : resolusi konflik, intimasi spiritual

Dependent variable : kepuasan pernikahan

Keterangan:

$$
\begin{array}{ll}
\text { KP } & \text { : Kepuasan pernikahan } \\
\text { RK } & \text { : Resolusi konflik } \\
\text { IS } & \text { : Intimasi spiritual }
\end{array}
$$

\section{Pembahasan}

Berdasarkan dari hasil uji statistik yang diperoleh, diketahui bahwa resolusi konflik dan intimasi spiritual memiliki besaran yang lebih tinggi ketika diuji secara simultan dibandingkan saat diuji secara parsial. Hal ini juga didukung dari nilai $\mathrm{R}^{2}$ yang lumayan besar yakni 0,320 . Nilai tersebut menunjukkan bahwa resolusi konflik maupun intimasi spiritual secara 
bersamaan memberikan kontribusi besar pada kepuasan pernikahan pasangan Kristiani beda etnis. Resolusi konflik dengan intimasi spiritual tersebut membantu pasangan beda etnis dalam mengatasi perbedaan standar, nilai dan prinsip dari dua budaya berbeda yang dianut oleh mereka (Fincham et al., 2011; Kusner et al., 2014; Lichter \& Carmalt 2008; Olson et al., 2008; Schneewind \& Gerhard, 2014; Utami \& Mariyati, 2015).

Beberapa penjelasan dapat dipaparkan terkait hasil penelitian ini bahwa resolusi konflik maupun intimasi spiritual secara simultan mampu memprediksi perubahan tingkat kepuasan pernikahan. Kepuasan pernikahan merupakan evaluasi secara keseluruhan dari kualitas hubungan antara pasangan suami istri yang bersifat subjektif (Bahr, Chappell, \& Leigh, 1983). Dalam hal ini, kepuasan pernikahan berkaitan erat dengan tingkat pemenuhan kebutuhan, harapan dan hasrat dalam suatu pernikahan. Perbedaan dalam kebutuhan, keinginan, dan harapan, baik pada suami maupun istri sering kali menimbulkan rasa kecewa dan berujung pada konflik rumah tangga (Stone \& Shackelford, 2007; Schneewind \& Gerhard, 2014). Keintiman yang dimiliki pasangan suami istri dapat memudahkan mereka mengetahui dan memenuhi kebutuhan, harapan, dan keinginan pasangannya (Bahr, Chappell, \& Leigh, 1983).

Seperti dikemukakan oleh Kusner et al. (2014), intimasi spiritual mencakup keterbukaan dan kejujuran diri individu terhadap pasangannya dan pemberian dukungan terhadap pasangannya terkait nilai dan prinsip spiritual. Intimasi spiritual mampu mendorong individu untuk saling terbuka satu sama lain bahkan dalam hal yang amat personal dan sensitif, yaitu spiritualitas (Cordova, 2009; Fincham et al., 2011; Kusner et al., 2014). Adanya keterbukaan dan pemberian dukungan spiritual pada pasangan beda etnis ini pada akhirnya mampu menciptakan resolusi konflik yang konstruktif (Olson \& Larson,
2008; Schneewind \& Gerhard, 2014).

Adanya peran signifikan resolusi konflik terhadap kepuasan pernikahan dalam penelitian ini sejalan dengan beberapa hasil penelitian sebelumnya yang menemukan adanya hubungan signifikan antara resolusi konflik dengan kepuasan pernikahan (Schneewind \& Gerhard, 2014; Utami \& Mariyati, 2015; Stinson et al., 2017). Penelitian Utami dan Mariyati (2015) berfokus pada persepsi resolusi konflik dan kepuasan pernikahan pada suami yang istrinya yang bekerja. Sedangkan, penelitian Schneewind dan Gerhard (2014) dilakukan pada pasangan dengan usia pernikahan lima tahun. Sementara penelitian Stinsol et al. (2017) ditujukan pada pasangan di Amerika Latin yang berbeda etnis.

Hasil penelitian ini juga menunjukkan bahwa peran intimasi spiritual terhadap kepuasan pernikahan lebih besar dibandingkan dengan resolusi konflik pada pasangan beda etnis yang menjadi subjek penelitian ini. Hasil ini sesuai dengan beberapa penelitian sebelumnya yang melaporkan bahwa adanya penyatuan nilai dan prinsip hidup pada pasangan suami istri dapat meningkatkan kepuasan pernikahan mereka (Lichter \& Carmalt, 2008; Fincham et al., 2011; Rostami \& Gol, 2014; Kusner et al., 2014). Penyatuan nilai dan prinsip hidup tersebut memerlukan intimasi spiritual. Pasangan dapat saling berbagi nilai dan prinsip hidup ketika mereka sudah memiliki hubungan yang intim secara spiritual. Mereka dapat saling terbuka dalam membahas hal-hal yang berkaitan dengan iman dan pergumulan hidup (Kusner, Mahoney, Pargament, \& Demaris, 2014). Nilai dan prinsip spiritual tersebut dapat memberikan makna hidup bagi individu (Fincham et al., 2011; Pustakasari,2014), dan memberikan makna bersama antar pasangan terhadap pernikahan mereka ketika nilai dan prinsip hidup mereka mencapai kesepahaman.

Berdasarkan Kusner et al. (2014), pasangan dapat disebut memiliki intimasi 
spiritual yang tinggi apabila keduanya mampu untuk terbuka dan jujur satu sama lain terkait iman mereka masing-masing. Hal ini sesuai dengan hasil penelitian ini dimana aitem B8 yang berbunyi "Saya merasa aman ketika benar-benar terbuka dan jujur kepada pasangan tentang iman saya" memiliki nilai rata-rata tertinggi pada skala intimasi spiritual di penelitian ini yakni sebesar 4,640.

Selain keterbukaan dan kejujuran tentang iman, intimasi spiritual yang tinggi juga dapat ditandai dengan kemampuan pasangan untuk saling bertukar pikiran mengenai identitas, menunjukkan sikap empati, dan saling memberikan dukungan tanpa bersikap menghakimi satu sama lain. Pernyataan ini didukung oleh hasil dari aitem B16 yang berbunyi "Saya mencoba untuk mendukung ketika pasangan saya mengungkapkan pertanyaan dan pergumulan spiritual" yang memiliki nilai ratarata aitem kedua tertinggi $(4,440)$ pada skala intimasi spiritual setelah aitem B8.

Kusner et al. (2014) dan Fincham et al. (2011) juga menyatakan bahwa ketika pasangan memiliki intimasi spiritual yang tinggi, maka pasangan mampu untuk bersikap vulnerable atau transparan satu sama lain. Hal ini meningkatkan rasa saling percaya dan keintiman di antara mereka sehingga pasangan mampu untuk saling memenuhi kebutuhan, keinginan, dan harapan dari pasangannya. Hal ini membantu pasangan dalam menangani konflik pernikahan dan membangun motivasi untuk melindungi kehidupan pernikahan mereka sehingga kepuasan pernikahan pasangan dapat terwujud.

Penelitian ini sejalan dengan hasil penelitian sebelumnya yang menemukan bahwa spiritual memiliki hubungan dengan relasi pernikahan (Fincham et al., 2011; Rostami \& Gol, 2014; Mahoney \& Cano, 2014; Kusner et al., 2014). Namun, penelitian Mahoney dan Cano (2014) tidak membahas hubungan intimasi spiritual dengan kepuasan pernikahan, melainkan dengan relasi spiritual. Relasi spiritual memiliki arti yang berbeda dengan intimasi spiritual. Relasi spiritual merupakan suatu cara dimana pasangan yang berbedabeda mampu untuk saling menyandarkan diri pada satu hal keyakinan dan perilaku spiritual, untuk menjadikan diri lebih baik. Inilah yang menjadi keterbatasan dalam penelitian terdahulu oleh Mahoney dan Cano (2014).

Penelitian lainnya (Fincham et al., 2011) juga lebih berfokus pada makna spiritualitas masing-masing individu antara suami dan istri America-Afrika. Penelitian ini tidak memperdalam terkait keintiman spiritualitas yang terjalin pada pasangan suami istri tersebut. Sedangkan, penelitian Rostami dan Gol (2014) lebih berfokus dalam membahas keterkaitan antara kecerdasan spiritual dengan kepuasan pernikahan.

Ketika resolusi konflik dan intimasi spiritual bersamaan dilakukan maka suami dan istri dapat bertukar pikiran mengenai prinsip dan nilai kerohanian, mereka pun akan saling mengenal, mendukung, dan menemukan persamaan prinsip dan nilai hidup. Persamaan prinsip dan nilai hidup selanjutnya menjadi sebagai landasan dalam melakukan resolusi konflik dalam rumah tangga (Lichter \& Carmalt, 2008; Olson \& Larson, 2008; Fincham et al., 2011; Kusner et al., 2014; Stinsol et al., 2017). Jika pasangan suami istri tidak memiliki landasan yang sama, yaitu dalam konteks ini adalah kitab suci yang diyakini, maka suami maupun istri akan berjuang untuk mengikuti pola pikir dan persepsinya sendiri. Hal ini yang seringkali menjadi akar dari kegagalan pasangan suami istri untuk menyelesaikan konflik dalam pernikahan mereka, terkhususnya bagi mereka yang berlatarbelakang budaya berbeda. Banyaknya perbedaan dari nilai dan prinsip yang dianut sulit untuk dicari jalan tengahnya apabila keduanya tidak memiliki prinsip dan nilai kerohanian yang sama, seperti halnya dalam konteks Kristiani ini adalah prinsip nilai yang bersumber dari Alkitab. 
Apabila pasangan memiliki intimasi spiritual, suami dan istri akan saling terbuka mengenai hal yang diharapkan dari pasangannya dan bercermin pada pedoman dalam kitab suci mengenai bagaimana seharusnya suami dan istri bersikap satu sama lain. Adanya keterbukaan dan pemberian dukungan membuat suami istri dapat menghargai perbedaaan yang dimiliki satu sama lain. Hal inilah yang membantu pasangan untuk dapat memiliki standar yang sama dalam menyatukan perbedaan pola pikir dan persepsi di antara keduanya. Penjelasan ini didukung oleh data penelitian ini dari karakteristik subjek yang adalah jemaat dari salah satu sinode gereja Kristiani. Nilai rata-rata resolusi konflik yang dimiliki subjek sebesar 3,310. Hal ini menunjukkan subjek penelitian sudah cukup efektif dalam mendiskusikan masalah, dan pendapat dengan pasangannya. Selain itu, subjek penelitian juga memiliki nilai rata-rata intimasi spiritual yang tinggi, yakni sebesar 4,250. Temuan ini mendukung pernyataan bahwa semakin tinggi intimasi spriritual yang dimiliki pasangan, semakin kuat landasan yang dimiliki untuk membentuk resolusi konflik yang konstruktif (Olson \& Larson, 2008; Kusner et al., 2014; Stinsol et al., 2017).

Penjelasan ini juga didukung oleh nilai rata-rata kepuasan pernikahan subjek penelitian ini yang tinggi, yakni sebesar 4,390. Hasil ini menunjukkan bahwa pasangan sudah dapat saling menerima kekurangan satu sama lain, menghargai, dan menemukan jalan keluar bersama terkait konflik rumah tangga mereka. Oleh karena itu, dapat dikatakan bahwa kepuasan pernikahan pada pasangan beda etnis dalam penelitian ini sudah dapat terwujud. Hasil ini tidak sejalan dengan penelitian Abas, Laisa, dan Talani (2014) serta Harahap (2016) yang menemukan bahwa latar belakang budaya menentukan tercapai atau tidaknya kepuasan pernikahan pada pasangan beda etnis. Berdasarkan hasil penelitian kali ini, diketahui bahwa rata-rata subjek penelitian memiliki kepuasan pernikahan yang tinggi sekalipun mereka berbeda etnis. Maka dari itu, peneliti menduga bahwa ada faktor lain, seperti hubungan interpersonal antara suami-istri dan mate value, yang jauh lebih mempengaruhi kepuasan pernikahan pasangan beda etnis daripada sebatas latar belakang budaya (Anjani \& Suryanto, 2006).

\section{Simpulan}

Berdasarkan hasil penelitian ini dapat disimpulkan bahwa resolusi konflik dan intimasi spiritual terbukti secara simultan dapat memprediksi perubahan yang terjadi pada kepuasan pernikahan pasangan beda etnis. Semakin tinggi intimasi spiritual dan semakin baik resolusi konflik yang dimiliki pasangan Kristiani beda etnis, maka semakin tinggi pula kepuasan pernikahan mereka. Secara parsial, resolusi konflik dan intimasi spiritual juga berperan signifikan terhadap kepuasan pernikahan. Intimasi spiritual memberikan kontribusi lebih besar dibandingkan dengan resolusi konflik terhadap kepuasan pernikahan. Dengan demikian, dapat disimpulkan bahwa adanya perbedaan diantara pasangan beda etnis yang se-iman tidak menjadi halangan untuk dapat mencapai kepuasan pernikahan ketika mereka memiliki kemampuan resolusi konflik dan intimasi spiritual.

\section{Saran}

Berdasarkan hasil penelitian ini, dapat disarankan pada para pasangan suami istri yang berbeda etnis dalam iman kepercayaan yang sama untuk meningkatkan kemampuan resolusi konflik dan intimasi spiritualnya guna memperoleh kepuasan dalam pernikahan mereka. Bagi penelitian selanjutnya, diharapkan dapat meneliti lebih lanjut mengenai pengaruh resolusi konflik dan intimasi spiritual terhadap kepuasan pernikahan pada pasangan umat beragama lain di Indonesia. 


\section{Daftar Pustaka}

Abas, F., Laisa, Z., \& Talani, N. S. (2014). Pernikahan dua etnis berbeda dalam perspektif komunikasi antar budaya. Jurnal Hasil Penelitian Skripsi Prodi Ilmu Komunikasi, 1(1), 1-11. http://kim.ung.ac.id/index.php/KIMF IS/article/ download/ 8180/8069.

Adi, D. S. (2017). Perilaku komunikasi antarbudaya pasutri kawin campur (perspektif dramaturgi). Jurnal Nomosleca, 3(2), 577-594. https://doi.org/10.26905/nomosleca.v $3 \mathrm{i} 2.2032$

Agustin, A., Raharjo, T., \& Suprihatini, T. (2013). Manajemen Konflik Antarpribadi Pasangan Suami Istri Beda Agama. Interaksi Online, 1( 2). https://ejournal3.undip.ac.id/index.ph p/interaksi-online/article/view/2205

Anjani, C. \& Suryanto. (2006). Pola penyesuaian perkawinan pada periode awal. INSAN, 8(3), 198-210. http://www.journal.unair.ac.id/downl oad-fullpapers-05\%20-

\%20Pola\%20Penyesuaian\%20Perka winan $\% 20$ pada $\% 20$ Periode $\% 20$ Awal .pdf

Apostolic Christian Counseling and Family Services. (2014). A triangular model of love. Retrieved from https://www.accounseling.org/upload ed/Marriage_and_Family/Triangular _Model of_Love.pdf

Apriani, N., Sakti, H., \& Fauziah, N. (2013). Penyesuaian diri wanita etnis Jawa yang menikah dengan pria etnis Cina. Empati, 2(4), 305-315. https://ejournal3.undip.ac.id/index.ph p/empati/article/view/7416

Ardhianita, I. \& Andayani, B. (2005). Kepuasan pernikahan ditinjau dari berpacaran dan tidak berpacaran. Jurnal Psikologi, 32(2), 101-111. https://doi.org/10.22146/jpsi.7074
Ardian, I. (2016). Konsep spiritualitas dan religiusitas (spiritual and religion) dalam konteks keperawatan pasien diabetes melitus tipe 2. Nurscope. Jurnal Keperawatan dan Pemikiran Ilmiah. 2(5). 1-9. https://doi.org/10.30659/nurscope.2.2 $.40-48$

Badan Pusat Statistik (BPS). (2019). Sensus Penduduk Indonesia 2010: Badan Pusat Statistik Indonesia. Retrieved from https://sp2010.bps.go.id/index.php/sit e/tabel?tid $=320 \&$ wid $=0$

Badan Kependudukan dan Keluarga Berencana Nasional. (2013). Angka perceraian di Indonesia tertinggi di AsiaPasifik. Retrieved from Badan Kependudukan dan Keluarga Berencana Nasional. Retrieved from http://www.bkkbn.go.id/ViewBerit a. $\operatorname{aspx}$ ?BeritaID $=967$

Bahr, S. J., Chappell, C.B., \& Leigh, G. K. (1983). Age at marriage, role enactment, role consensus, and marital satisfaction. Journal of marriage and family, 45(4), 795-803. https://doi.org/10.2307/351792

Brelsford, G. M. \& Mahoney, A. (2008). Spiritual disclosure between older adolescents and their mothers. Journal Family Psychology, 22(1), 62-70. https://doi.org/10.1037/08933200.22.1.62

Bunyamin, A. S. (2012). Sakral dan profan dalam kaitan dengan ritus dan tubuh: Suatu telaah filsafati melalui agama dan konsep diri. MELINTAS International Journal of Philosophy and Religion, 28(1), 23-38. http://journal.unpar.ac.id/index.php/ melintas/article/view/287

Choiriah, M. (2016, September 20). Indonesia Darurat Perceraian! 
Retrieved from https://www.merdeka.com/khas/indo nesia-darurat-perceraian-trenperceraian-meningkat- $1 . \mathrm{html}$

Cordova, J. V. (2009). The marriage checkup: A scientific program for sustaining and strengthening marital health. Plymouth, UK: Rowman \& Littleton.

David, P., \& Stafford, L. (2013). A relational approach to religion and spirituality in marriage: The role of couples' religious communication in marital satisfaction. Journal of Family Issues, 36, 232-249. https://doi.org/10.1177/0192513X13 485922

Dewi, E.M.P., \& Basti (2008). Konflik perkawinan dan model penyelesaian konflik pada pasangan suami istri. Jurnal Psikologi, 2(1), 42-51. https://ejournal.gunadarma.ac.id/inde x.php/psiko/article/view/243/184

Fincham, F. D., Ajayi, C, \& Beach, S. R. H. 2011. Spirituality and marital satisfaction in African American couples. Psychology of Religion and Spirituality, 3(4), 259-268. https://doi.org/10.1037/a0023909

Grable, J. E. \& Britt, S. (2006). A further examination of the validity of the kansas marital satisfaction scale: Implications for financial consultants. Journal of Personal Finance, 5(2), 18. Retrieved from http://www.planipedia.org/index.php/ A_Further_Examination_Of_The_Va lidity_Of_The_Kansas_Marital_Satis faction_Scale:_Implications_For_Fin ancial_Consultants

Harahap, R. E. (2016). Problematika perkawinan beda kultur: Studi kasus pada pasangan suami istri beda suku di Kelurahan Kober. Undergraduate thesis. Institut Agama Islam Negeri, Purwokerto. Retrieved from https://core.ac.uk/download/pdf/2953 20791.pdf

Hariyono, P. (2006). Menggali latar belakang stereotip dan persoalan etnis Cina di Jawa. Semarang: Mutiara Wacana.

Igbo, H. I., Grace, A. R., \& Christiana, E. O. (2015). Relationship between duration of marriage, personality trait, gender and conflict resolution strategies of spouses. Procedia Social and Behavioral Sciences, 190, 490-496.

https://doi.org/10.1016/j.sbspro.2015. 05.032

Kumparan (2019, November 27). Kami Membandingkan Jumlah Pernikahan dan Perceraian di Indonesia. Retrieved from https://kumparan.com/kumparannews /kami-membandingkan-jumlahpernikahan-dan-perceraian-diindonesia-1sKM5fAHafr

Kurniawan, J. E., \& Setiawan, J. L. (2016). Pengembangan model dukungan sosial orangtua berbasis relasi pernikahan untuk meningkatkan entrepreneurial self-efficacy. (Laporan penelitian tidak diterbitkan). Universitas Ciputra, Surabaya.

Kusner, K. G., Mahoney, A., Pargament, K. I., \& Demaris, A. (2014). Sanctification of marriage and spiritual intimacy predicting observed marital interactions across the transition to parenthood. Journal of Family Psychology, 28(5), 604614.https://doi.org/10.1037/a003698 9

Lee, S., Balkin, R. S., \& Fernandez, M. A. (2017). Asian intercultural marriage couples in the United States: A study in acculturation and personality traits. The Family Journal. 25(2), 164-169. 
https://doi.org/10.1177/10664807176 97951

Lichter, D. T. \& Carmalt, J. H. (2008). Religion and marital quality among low-income couples. Social Science Research, 38, 168-187. https://doi.org/10.1016/j.ssresearch.2 008.07.003

Mahoney, A. \& Cano, A. (2014). Introduction to the special section on religion and spirituality in family life: Delving Into relational spirituality for couples. Journal of Family Psychology, 28(5), 583-586. https://doi.org/10.1037/fam0000030

Nugroho, A. B., Lestari, P., \& Wiendijarti, I. (2012). Pola komunikasi antarbudaya Batak dan Jawa di Yogyakarta. Jurnal Komunikasi, 1(5), 403-418. https://doi.org/10.24329/aspikom.v1i 5.44

Olson, D. H. \& Larson, P. J. (2008). Preparelenrich: Customized version. Minneapolis: Life Innovations Inc.

Olson, D. H., Olson-Sigg, A., \& Larson, P. (2008). The couple check up. Nashville: Thomas Nelson, Inc.

Pramudito, A. A. (2017). Merenda Cinta Melintas Budaya Hingga Senja Tiba (Studi Literatur tentang Perkawinan Antar-Budaya). Buletin Psikologi, 25(2), 76-88. https://doi.org/10.22146/buletinpsiko $\operatorname{logi} .27233$

Purnawan, D. (2016, September 26). Tingkat Perceraian di Indonesia termasuk yang Tertinggi di Dunia. Retrieved from http://www.gulalives.co/2016/09/26/t ingkat-perceraian-di-indonesiatermasuk-yang-tertinggi-di-dunia/

Rostami, A. M., \& Gol, H. C. (2014). Prediction of marital satisfaction based on spiritual intelligence. Procedia-Sosial and Behavioral Sciences, 116, 2573-2577. https://doi.org/10.1016/j.sbspro.2014. 01.613

Schneewind, K. A., \& Gerhard, A. K. (2014). Relationship personality, conflict resolution, and marital satisfaction in the first 5 years of marriage. Family Relations, 51(1), 63-71.https://doi.org/10.1111/j.17413729.2002.00063.x

Skinner, A. L., \& Hudac, C. M. (2017). "Yuck, you disgust me!" Affective bias against interracial couples. Journal of Experimental Social Psychology, 68, 68-77. https://doi.org/10.1016/j.jesp.2016.05 .008

Stinson, M. A., Bermudez, J. M., Gale, J., Lewis, D., Meyer, A. S., \& Templeton, G. B. (2017). Marital satisfaction, conflict resolution styles, and religious attendance among latino couples: using the actor-partner interdependence model. The Family Journal: Counseling and Therapy for Couples and Families, 25(3), 215-223. https://doi.org/10.1177/10664807177 10645

Stone, E. A., \& Shackelford, T. K. (2007). Marital satisfaction. Encyclopedia of Social Psychology, 541-54. https://dx.doi.org/10.4135/97814129 56253

Tuapattinaya, Y. I. F., \& Hartati, S. (2014). Pengambilan keputusan untuk menikah beda etnis: Studi fenomenologis pada perempuan Jawa. Jurnal Psikologi Undip, 13(1), 34-41.

https://doi.org/10.14710/jpu.13.1.3441

Utami, T., \& Mariyati, L. I. (2015). Persepsi terhadap resolusi konflik suami dan kepuasan pernikahan pada istri bekerja di Kelurahan Bligo. Seminar Psikologi \& Kemanusiaan, 407-412. Retrieved from 
http://mpsi.umm.ac.id/files/file/407412\%20Trisni\%20Utami.pdf

Yamaguchi, A., Kim, M.S., Oshio, A., \& Akutsu, S. (2016). Relationship between bicultural identity and psychological well-being among American and Japanese older adults. Journal of Healthy Psychology Open, $3(1)$, $1-12$. https://doi.org/10.1177/20551029166 50093

Zahra, S. A., \& Caninsti, R. (2016). Hubungan antara kepuasan pernikahan dengan spiritualitas pada istri bekerja yang berada dalam tahap pernikahan families with school children. Jurnal Psikogenesis, 4(2), 215-223.

https://doi.org/10.24854/jps.v4i2.351

Zarei, E., \& Ahmadisarkhooni, T. (2013). Relationships between spiritual quotient and marital satisfaction level of men, women, and couples refered to consultancy center of Bandar Abbas. Iranian Journal of Psychiatry Behavioral Sciences. 7(1), 45-51. Retrieved from https://www.researchgate.net/publica tion/260917147 